\title{
Kamgot at the lagoon's edge: Site position and resource use of an Early Lapita site in Near Oceania
}

\author{
Glenn R. Summerhayes, Katherine Szabó, Matthew Leavesley \\ and Dylan Gaffney
}

\begin{abstract}
Early Lapita occupation is normally associated with stilt house occupation. This is easily demonstrated in those sites where waterlogged deposits preserve wooden house posts. Yet in many other locations the identification of stilt occupation depends on palaeobeach reconstructions. Here we present evidence from the Early Lapita site of Kamgot, Babase Island, Anir Group, New Ireland Province, Papua New Guinea, on the nature of occupation, which is crucial in modelling the nature of settlement and subsistence patterns.
\end{abstract}

\section{Lapita stilt villages: The evidence}

Lapita sites, and Lapita lifeways at large, are closely linked with the sea. The colonisation of southwestern Remote Oceania by Lapita settlers speaks to their abilities as navigators and seafarers, and the coastal location of sites coupled with the dominance of marine fauna in subsistence remains also reinforces the seaward focus. Exactly where Lapita sites are centred on the land/seascape, and how we should conceive of this placement in both geographical and social terms have been the subject of some debate. There is some evidence for stilt villages and also some for villages on raised marine terraces, with the stilt village cases in particular receiving detailed treatment concerning the specifics of location and depositional/formation processes (e.g. Felgate 2007; Gosden and Webb 1994; Kirch 2001; Sheppard and Walter 2009; Summerhayes et al. 2009, 2010). We investigate this question here for the Early Lapita site of Kamgot on Babase Island, Anir group, New Ireland Province, Papua New Guinea. 


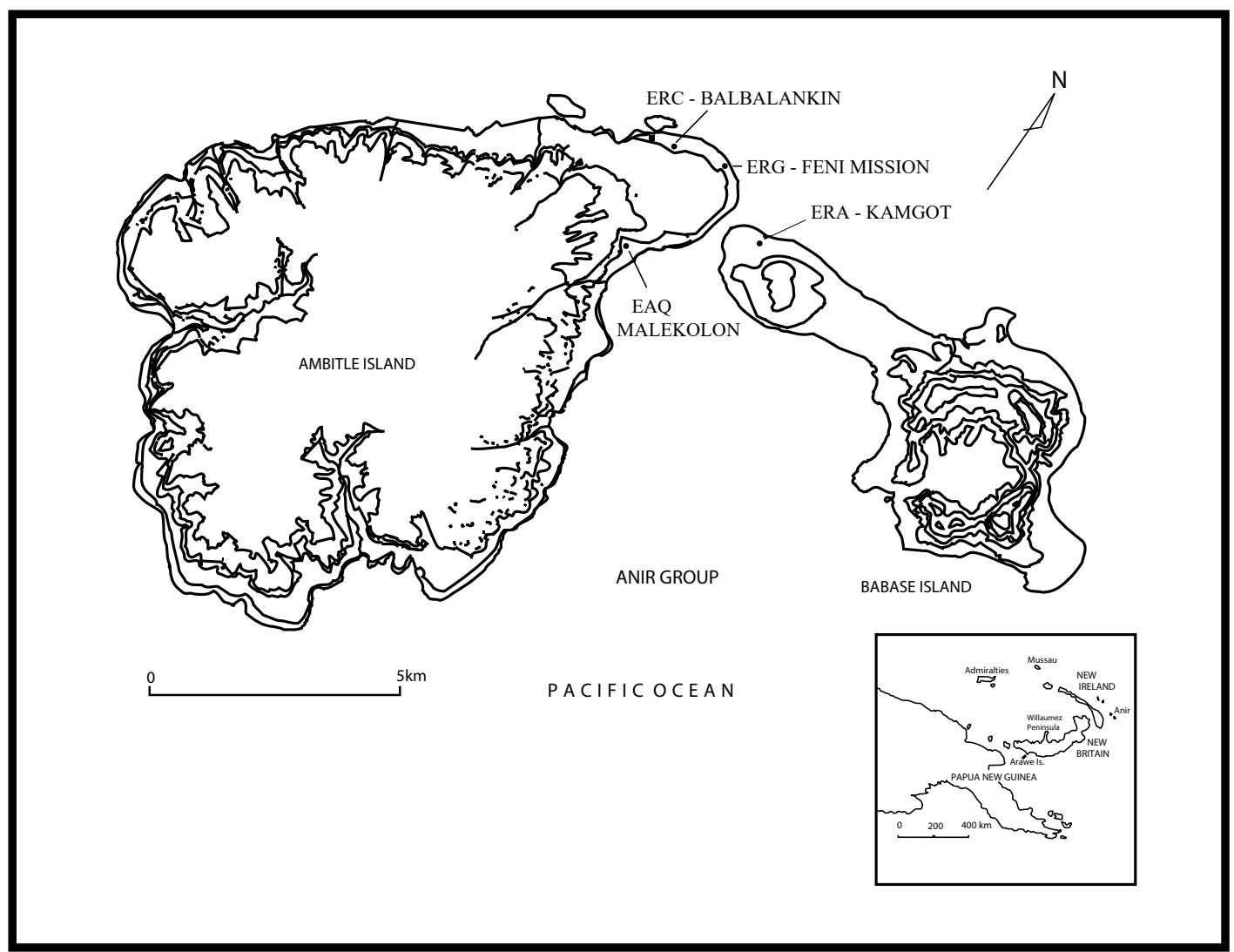

Figure 4.1. The Island of Anir with the location of Kamgot (ERA).

Source: lllustration by authors.

Roger Green's original formulation of the Lapita Cultural Complex (Green 1979) noted that sites tended to be located on recently exposed marine terraces, beaches and reef platforms. Kirch (1997:163) further pointed out that this physical situation applied to around 80 per cent of all known Lapita sites. Local tectonic variation, as well as geomorphological effects of the recession of the mid-Holocene high sea stand, mean that these coastal sites are now variably positioned in relation to modern coastlines (Kirch 1997:163-164). The situation appears to be somewhat different for Early Lapita sites in the Bismarck Archipelago, where clear evidence in the form of waterlogged deposits indicates the presence of stilt villages built over the intertidal zone at both Talepakemalai in Mussau and Makekur and Apalo in the Arawe Islands (Gosden 1990; Gosden and Webb 1994; Kirch 2001). In both of these cases, the waterlogged remains of structural features give clear signs of the original nature of some of the buildings and their location, and waterlogged plant remains provide an additional window onto Lapita subsistence and arboriculture (Lepofsky 1992; Matthews and Gosden 1997). Evidence for stilt house occupation from non-waterlogged deposits based on palaeo-shoreline reconstructions is found at the Early Lapita site of Tamuarawai on Emirau (Summerhayes et al. 2010), the later Lapita site of Nukuleka in Tonga (Burley 2016), and later sites from the Solomons (see Felgate 2007; Sheppard and Walter 2009). Evidence for stilt houses positioned in the intertidal zone is overwhelmingly found in Near Oceania, where settlement patterns of pre-existing populations may have been influential in the placement of Lapita villages. There is claimed evidence of such a stilt village at the site of Bourewa in Fiji, although this interpretation seems to be based simply on the presence of postholes (Nunn 2007:167), which, in themselves, do not indicate an intertidal location. The site is also too high above sea level to have been intertidal, even during the high sea stand, although areas surrounding the site may have been. 
Excavations in the Arawe Islands as part of the Lapita Homeland Project located evidence of several Lapita stilt villages, including two with preserved remains of wooden structures: Makekur (FOH) and Apalo (FOJ). The following information is drawn from Gosden and Webb (1994) and Gosden (1990). Apalo is a beach site located on the protected eastern coast of Kumbun Island. The underlying substrate is a mixture of limestone and mid-Holocene corals, with white beach sand lying above, the upper portions of which contained dense accumulations of Lapitaperiod material culture and subsistence refuse. During the time of deposition, Gosden and Webb (1994:37) estimate that the water would have been 1.5-2.0 m deep at high tide. Waterlogged evidence of Lapita dwelling structures was found in the form of shaped planks and posts, with their placement within the site indicating structures built over water. Reconstructed sea levels and geomorphological evidence suggest that the underlying substrate would have been exposed at low tide, especially as sediment rapidly accumulated throughout the course of occupation (Gosden and Webb 1994:40 including Figure 8).

The Makekur site is on a sandspit on Adwe Island that even now is no more than $1 \mathrm{~m}$ above high tide at any point (Gosden and Webb 1994:41). As with Apalo, the artefact-rich occupation sands sit atop a hard reef substrate, but in the case of Makekur, not only were the original stilt houses located further seaward over the reef, but the reef substrate was not exposed even at low tide (Gosden and Webb 1994:42). During the course of occupation, sediments accumulated around the house posts, transforming the substrate. Other stilt villages excavated in the Arawe Islands include the Lapita-period Paligmete site, and the Post-Lapita Winguru site, on Pililo Island (Gosden and Webb 1994).

Evidence for Early Lapita stilt settlements are also provided by two sites on Eloaua Island in the Mussau Group. Talepakemalai (ECA) and Etakosarai (ECB), originally recorded by Egloff (1975), were excavated under the leadership of Kirch over multiple seasons as part of the Lapita Homeland Project (Kirch 2001). Talepakemalai is an extensive site with zones where wooden stilt house structures and plant remains have been anaerobically preserved. The initial occupation zone was over a 'sandy reef flat', although the locus of settlement shifted through time, as older areas prograded and infilled (Kirch 2001:132). The smaller Etakosarai site on the western part of Eloaua Island faced Talepakemalai across a reef flat, with the stilt dwellings there resting on coarse-grained calcareous sand, interspersed with coral rubble and waterworn shell as well as articulated tellin (Tellinidae) shells in death position. These features of the layer underlying the settlement debris indicate a palaeobeach substrate, which Kirch (2001:137) associates with the mid-Holocene high sea stand. The specific conditions allowing anaerobic waterlogging of some remains at Talepakemalai do not exist at Etakosarai.

\section{The case of Kamgot: A stilt village on Babase Island?}

Unlike Apalo, Makekur and Talepakemalai, there are no waterlogged zones at Kamgot preserving structural features of stilt dwellings. Thus, we must look to other features of the site and the distribution of materials to investigate precisely where the initial zones of settlement were located relative to the shoreline, and how the settlement evolved through time. Here, we incorporate observations about the nature and build-up of sediments through time following the observations of Gosden and Webb (1994) and Kirch (2001) and add data about the Kamgot molluscan assemblage, which provide information as to the nature of the underlying substrate. Following from an understanding of the placement of the site, we then investigate the various niches from which subsistence evidence derives, and in particular the balance between terrestrial and aquatic fauna. This information then guides an assessment of the balance, and integration, of 'seaward' and 'landward' foci within the context of Early Lapita settlement and subsistence. 
The site of Kamgot (site code ERA from the National Museum and Art Gallery site register) is located on the north-west coast of Babase Island, Anir Island Group (see Figure 4.1). Babase is mostly volcanic, but its western end is made up of raised limestone. Today the site is $100 \mathrm{~m}$ inland from the high-tide mark, with the old raised reef forming a raised beach front. There is an accumulation of clays at the base of the steep rise, and the area is swampy (see Figure 4.2a). Yet, during the initial Lapita occupation the settlement was spread over both a sand bar at or just above the high-water mark (see below) and stilt village occupation over a shallow lagoon parallel to an outer reef some $80 \mathrm{~m}$ away, with swamp or fresh water available on the landward side (Figure 4.2b). More detail on this is outlined below.

The area was originally targeted for survey in 1997. Prior to surface sampling in the 1997 field season, a local community leader, Bruno Sianlon, from Kamgot village showed Summerhayes pottery he recovered from digging a well behind the hamlet. The well was located $114 \mathrm{~m}$ south of the high-tide mark, and was abandoned when the hard coral was reached. The pottery was Early Lapita in decorative style (Summerhayes 2000:171). A series of excavations was undertaken during four field seasons from 1997 to 2001 (Summerhayes 2000; Summerhayes et al. 2009).

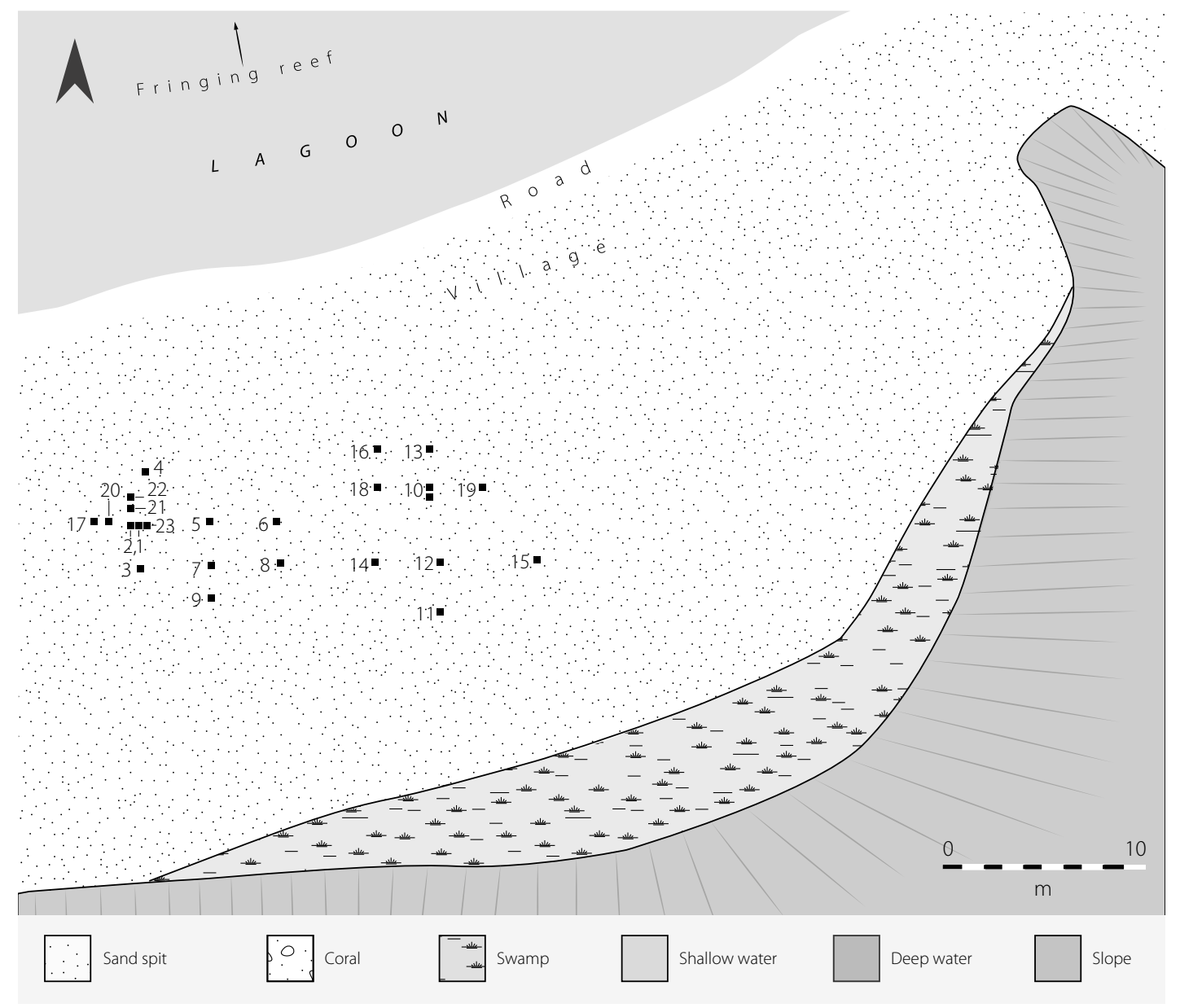

Figure 4.2a. Plan of Kamgot (ERA) with modern landscape.

Source: Illustration by authors. 


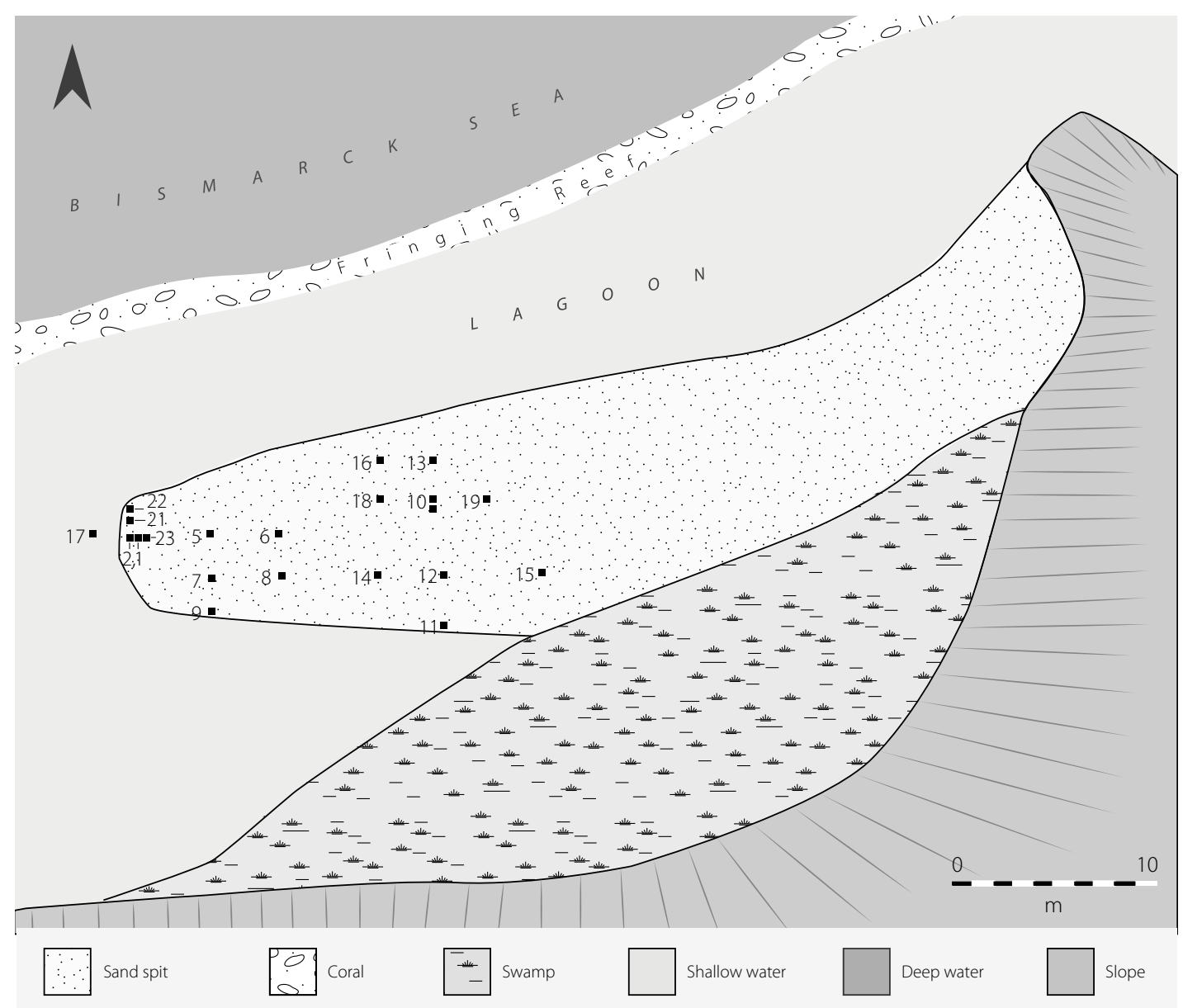

Figure 4.2b. Plan of Kamgot - Early Lapita.

Source: Illustration by authors.

\section{Spread of material}

A number of points can be made about the site. First, surface material extends over $400 \mathrm{~m}$ in an east-west direction, and $60 \mathrm{~m}$ in a north-south direction (see Figure 4.2a). Seventy-seven square metres were excavated in 23 test pits (TPs) over an area of 200 by $100 \mathrm{~m}$. Figure 4.2a shows the plan of Kamgot and the postulated extent of deposition, while Figure 4.2b shows Kamgot c. 3300 years ago. Second, the spread of archaeological materials at the western end of the site is parabolic-shaped in distribution, with TP 17 forming the westernmost limit. No surface or subsurface material was found west of TP 17, where the ancient basal coral reef floor becomes much deeper. 
Common across the whole site are three depositional layers. A dark brown humic topsoil, Layer 1, ranges from a few to $10 \mathrm{~cm}$ in depth. This layer has abundant roots and is basically a gardening soil, highly disturbed. This overlies Layer 2, which is a light brown orange sand that varies in depth across the site (see below). This layer slopes from east to west. Coral clumps are found within the layer. The bottom layer, Layer 3, is a coarse white sand sitting on the coral lagoon floor, and again varies in depth across the site. Archaeological deposits are primarily found in the orange/brown sand layer (Layer 2), which is evidence of deposition on land, or in smaller amounts in the white beach sand (Layer 3), suggesting deposition directly in water before the build-up of both terrestrial-based sediments from landward erosion and the accumulation of occupation-related organic detritus. Only in the westernmost pit, TP 17, and in TP 21 was considerable material found within Layer 3, suggesting continued stilt house occupation over water during the Early Lapita period, unlike TPs 1, 2 and 23, where a sand spit quickly built up at or just above the high-water mark.

The western test pits include 1, 2, 17, 20, 22 and 23 (see Figures 4.2a, 4.2b and 4.2c for their locations). All were 1 by $1 \mathrm{~m}$ excavations, except TP 2 , which was 2.5 by $1 \mathrm{~m}$, and TP 21, which was 2 by $1 \mathrm{~m}$.

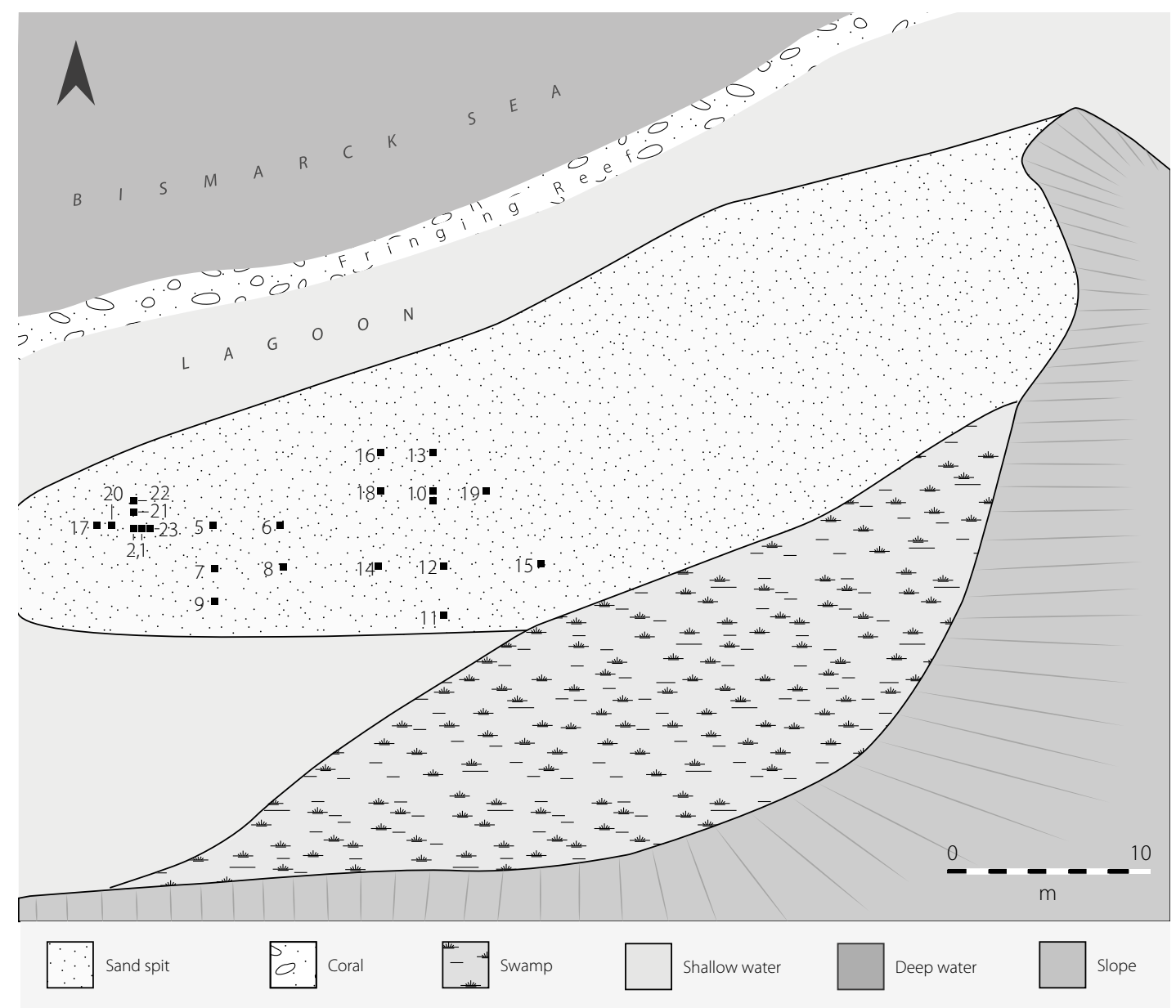

Figure 4.2c. Plan of Kamgot - Middle Lapita.

Source: Illustration by authors. 
While the depth of deposits ranged from 1.5 to $2 \mathrm{~m}$ before hitting basal coral/reef near TP 17 to 23 , the excavations further east were not deep, with thinner deposits and the underlying reef platform appearing at much shallower depth, although the density of cultural material per cubic metre remained the same. That is, the amount of cultural material is directly proportional to the thickness of Layer 2. The orange/brown cultural layer (Layer 2) thins out from west to east across the site. Towards the eastern end of the site, the deposits become shallow with the basal coral/reef found just below the surface, and scatters of pottery and stone found on the surface. Here much of the orange/brown occupational layer (Layer 2) has disappeared due to uplift and subsequent erosion, with much denser amounts of surface material than in the western part of the site. The island of Babase is actively volcanic, with evidence of recent tectonic uplift. The greatest uplift is towards the eastern end of the site. For instance, the basal coral of TP 15 in the east was $4.25 \mathrm{~m}$ above sea level ( $\mathrm{m}$ asl), while in the west the base of TP 17 was $2.35 \mathrm{~m}$ asl, TP 2 was $2.4 \mathrm{~m}$ asl and TP $12.54 \mathrm{~m}$ asl. Thus, the uplift on Babase is not uniform across the island, but greater in the east. The thickness of Layer 2 is directly related to the amount of uplift and the presence of previous occupation. In the other direction, there are no cultural remains (or Layer 2) to the west of TP 17 where the ancient lagoon floor is much deeper. Changes to the environment are seen as a combination of human and natural processes (Summerhayes et al. 2009:740).

For the purposes of this paper, we concentrate on those westerly test pits where the deepest and most intact occupational materials are found (see Figure 4.2a). As noted above, the earliest occupation was both over water and soon after on a nearby sand spit (Figure 4.2b). Earliest occupation on the spit is evident from deposition in TPs 1, 2, 21, 22 and 23. In these test pits there was material deposited, albeit in small amounts, in the distinct white sands of Layer 3 which overlays the coral bedrock. The artefactual material was primarily deposited onto dry land (Layer 2). That is, differences in cultural deposition across the site during Early Lapita are observed between TPs 17 and 21 and the other test pits. From TP 17, 60 per cent of the pottery $(\mathrm{n}=1243)$ was deposited into Layer 3. A similarly high percentage is also found in TP 21 with 50 per cent $(n=1326)$, suggesting initial stilt occupation over the lagoon or intertidal areas. The other test pits have a smaller proportion of pottery in Layer 3, suggesting the formation of the sand spit (Layer 2) soon after occupation: TP 1 has 15 per cent $(\mathrm{n}=453)$; TP 2 Square A has 14 per cent $(n=862)$; TP 22 has 20 per cent $(n=294)$; and TP 23 has only 3 per cent $(n=79)$. In these test pits the primary deposition is into Layer 2.

TP 17 is located $20 \mathrm{~m}$ to the west of TP 2 . The differences in deposition seen in Layer 2 from houses on the sand spit (TPs 1, 2, 22 and 23) and stilt house occupation over the water (TP 17 and 21) as seen in Layer 3 will be further explored in Chapter 18 (this volume) when outlining faunal and shell distributions and consumption across the site. Over time, the lagoon was infilled with various deposits, with later occupation evident in TP 20, equidistant between TP 2 and 17 (see Figures 4.2c and 4.3). 


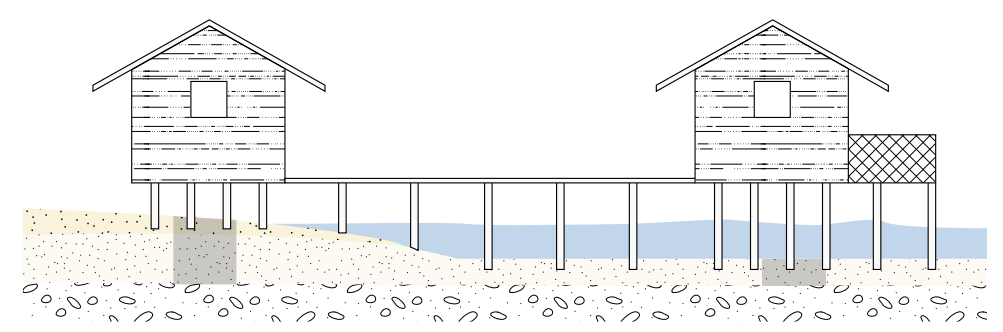

TP1, 2, 23

TP17

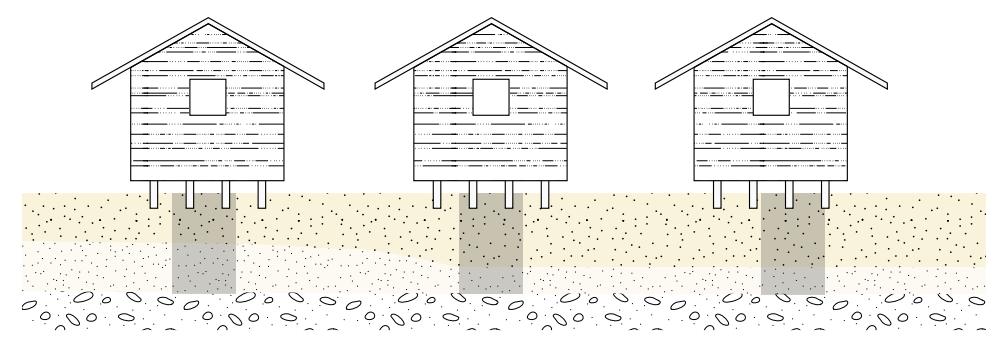

TP1, 2, 23

TP20

TP17

2800 BP
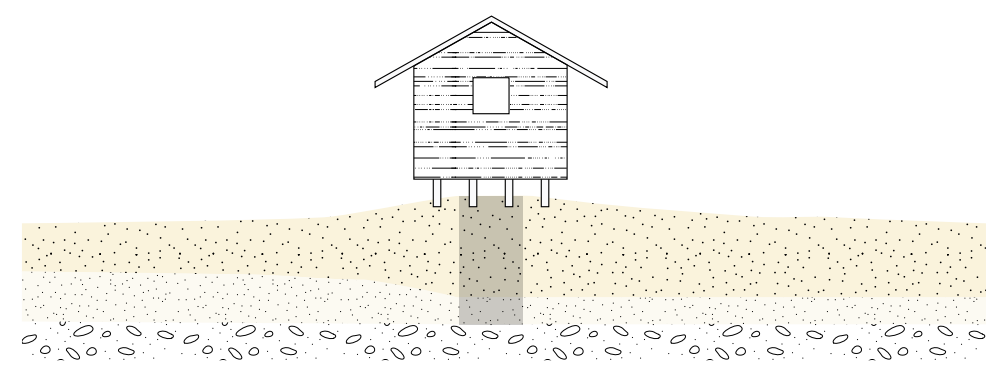

TP20

Layer 2-yellow/brown sand
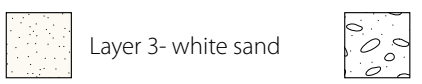

Coral bedrock

Figure 4.3. Kamgot depositional history.

Source: Illustration by authors.

These patterns of deposition are reinforced in the shell data in two ways: (1) the overall densities of shell recovered from particular test pits and layers, and (2) the relative numbers of specific species indicating the presence of particular habitats. Molluscan shell densities are highly variable across the site, as are the relative proportions of 'natural' (i.e. in situ or naturally introduced) shell versus cultural (i.e. midden and industrial) shell. Table 4.1 clearly demonstrates that molluscan shell is not only concentrated in TPs 20 and 23 in absolute terms, but, in accordance with sherd distributions, is also largely contained within Layer 2.

Looking in a more detailed way at the Kamgot molluscan assemblage, 'natural' and 'cultural' shell can be, at least to some extent, separated, with the natural component providing insights into the nature of substrates, vegetation and littoral zonation. First, 175 (MNI, minimum number of individuals) shells were separated out from the main assemblage and not included in further totals. These shells included ones that had evidence of beach-rolling, completed bore-holes from predatory gastropods, and those that had use-wear indicative of terrestrial hermit crab use and deposition (see Szabó 2012). All of these indicators mean that these shells were probably not 
introduced to the deposits via a human vector, nor were they used for economic purposes. More importantly for this analysis, a further 4861 (MNI) shells were isolated whose presence was not linked to human gathering for food or the procurement of raw materials, but that lived and died within the bounds of the site itself (in situ natural). These are typically small to very small species that naturally inhabit the highest reaches of the intertidal and 'splash' zones, and those associated with coastal vegetation. The major species included in these categories are the diminutive nerites Clithon oualaniense and Vittina variegata, which cluster together on hard substrates in the highest areas of the intertidal zone, especially in areas of freshwater seepage; Planaxis sulcatus, which likewise cluster on rocks within the high intertidal zone; and the air-breathing Pythia scarabaeus, which lives on coastal vegetation, and in particular Pandanus spp. trees (Abbot 1991:117; Morton and Raj n.d.:168) (see Figure 4.4). Together, these four species contribute 4753 (MNI), or 54 per cent, to the total Kamgot shell assemblage.
Table 4.1. Total numbers (MNI) of molluscan shells recovered from analysed test pits and their respective layers at Kamgot.

\begin{tabular}{|l|r|r|}
\hline Test pit & Layer & Total shell (MNI) \\
\hline TP1A & 2 & 160 \\
\cline { 2 - 3 } & 3 & 143 \\
\hline TP2 & 2 & 203 \\
\cline { 2 - 3 } & 3 & 136 \\
\hline TP10B & 1 & 14 \\
\cline { 2 - 3 } & 2 & 10 \\
\cline { 2 - 3 } & 3 & 1 \\
\hline TP18A & 1 & 35 \\
\cline { 2 - 3 } & 2 & 28 \\
\cline { 2 - 3 } & 3 & 10 \\
\hline TP20A & 1 & 64 \\
\cline { 2 - 3 } & 2 & 3970 \\
\cline { 2 - 3 } & 3 & 6 \\
\hline TP21 & 1 & 30 \\
\cline { 2 - 3 } & 2 & 380 \\
\cline { 2 - 3 } & 3 & 143 \\
\hline TP23 & 1 & 185 \\
\cline { 2 - 3 } & 2 & 3078 \\
\cline { 2 - 3 } & 3 & 156 \\
\hline
\end{tabular}

Source: Authors' data.

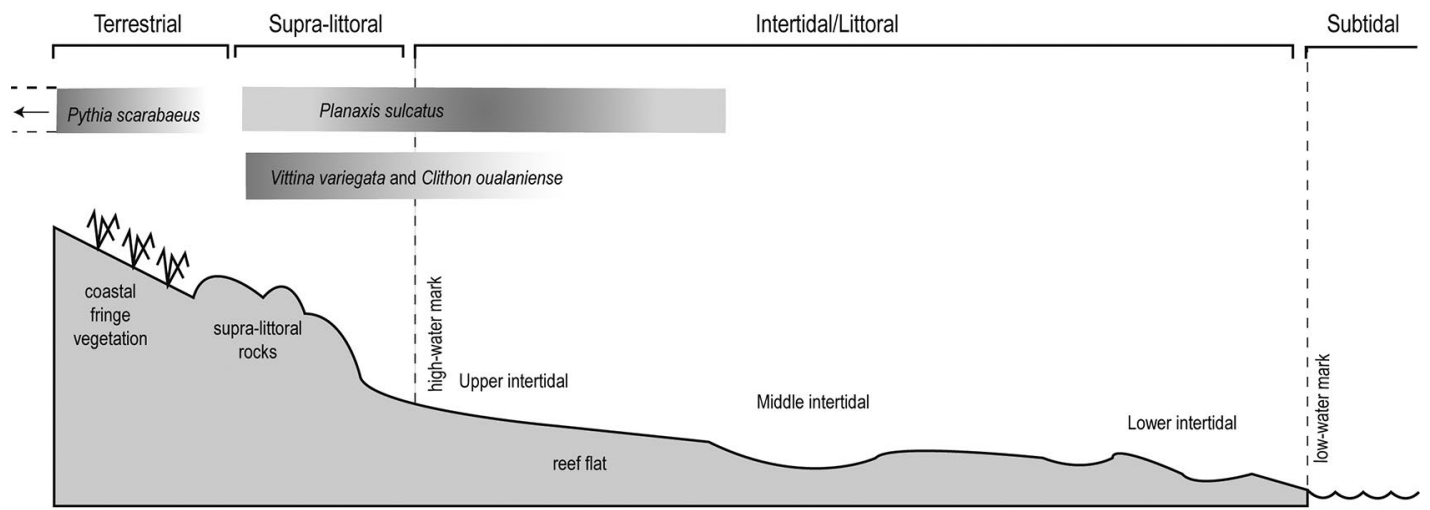

Figure 4.4. Schematic representation of reef flat/coastal fringe zonation, showing the zones of occurrence for the major species represented in the Kamgot supra-littoral shell assemblage. The gradient shows density of occupation within each zone. Source: Illustration by authors.

The distribution of shells in the natural category across the Kamgot test pits is not even (see Figure 4.5), with TPs 1, 20 and 23 all being at last half composed of natural, in situ shell. These shells have accumulated in Layer 2, and thus do not represent underwater deposition. The types of shell present indicate that these squares were at, or just above, the high-water mark at the time of deposition and that coastal vegetation, most likely in the form of Pandanus, was present. The position of TPs 20 and 23 at or just above the high-tide mark is also indicated by accumulations of the small bivalve Atactodea striata, which lives just below the surface of coarse sand at the high-water mark. Although $A$. striata is sometimes gathered and eaten by children 
(Katherine Szabó, Kamgot village, personal observation), its occurrence here in association with so many small neritids and $P$. sulcatus suggests that it is also an in situ natural occurrence in these test pits.

While these dense accumulations of upper intertidal molluscs in TPs 20 and 23 accord well with the position of the squares within the site relative to palaeoenvironmental/palaeolittoral reconstructions, what does not accord are the substrate requirements. V. variegata, C. oualaniense and $P$. sulcatus are obligate hard substrate dwellers, and there is little evidence of stable hard substrates in TPs 20 and 23, or the surrounding squares. It is possible that they washed in, but the stark differences in numbers between test pits in close proximity to each other at the western end of Kamgot makes simple deposition through 'swash' less likely. One possibility is that hard substrates once present are now absent; this is perhaps not as unlikely as it first appears.

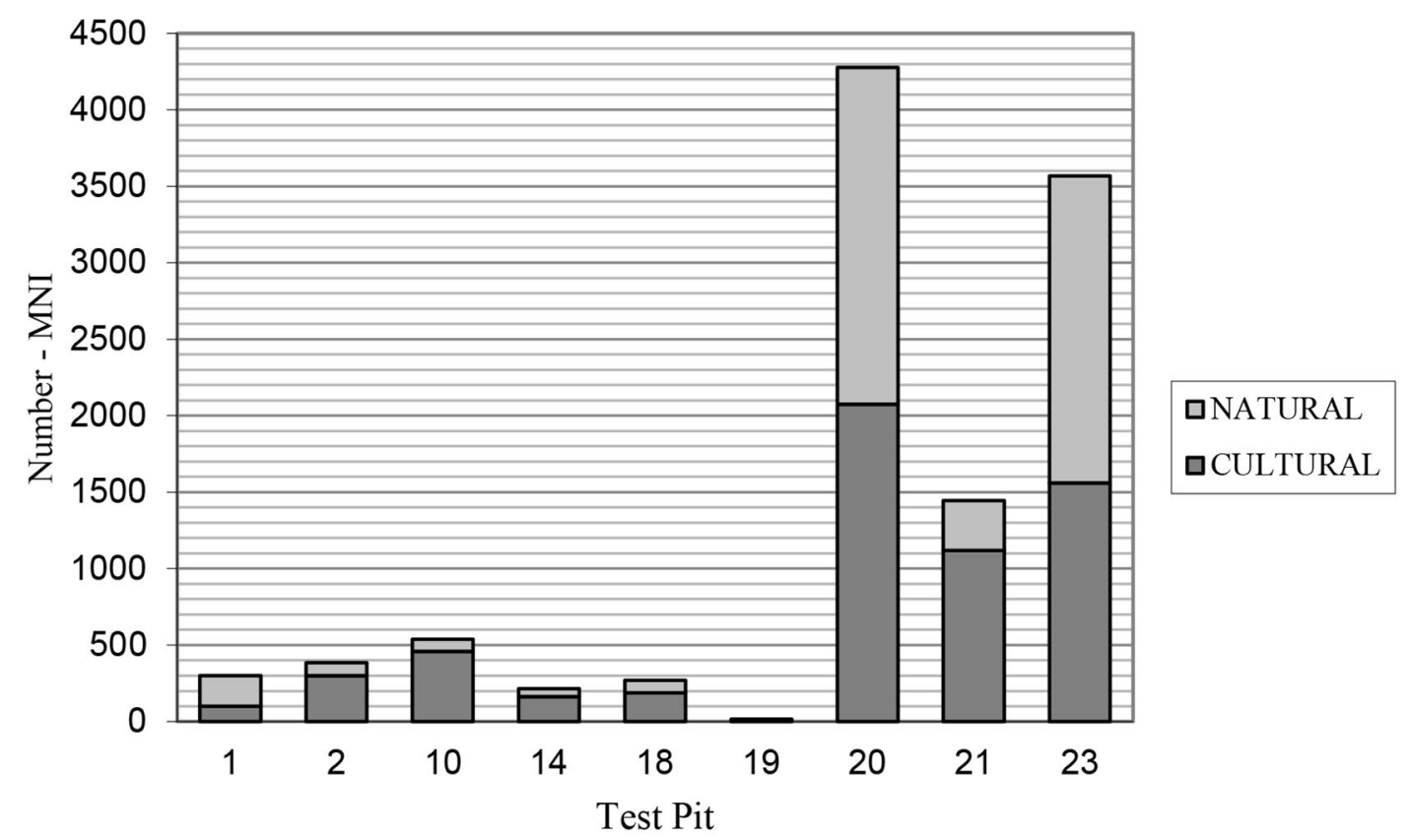

Figure 4.5. Graph showing the proportion of midden/cultural shell to in situ natural shell across major test pits at Kamgot.

Source: Authors' data.

Gosden and Webb (1994:40) noted for Apalo and Makekur on the Arawe Islands that analysis indicated that the 'stilts must have been originally founded in thin deposits of sand or (surprisingly) directly among the coral heads of the reef surface'. Thus, rather than being sunk into sand, stilts rested on, or were nestled into, a hard substrate. Although TPs 21 and 23 and surrounds at Kamgot do not indicate the presence of a hard substrate, the attendant in situ molluscan fauna do. Even more perplexingly, these small gastropods associated with hard substrates are only present in Layer 2 from spit 9 upwards, with the Layer 3 white sand molluscan assemblage containing no hints of anything other than the white sandy substrate in which they are found. A possibility emerges if we consider the different ways in which stilt houses are constructed now in the western Melanesian region. While stilts are sometimes buried or bored into the substrate (as in 'pile dwellings'), boulder platforms are sometimes deliberately constructed from exogenous materials, and the stilts sit on, or are braced within, this platform ('pier dwellings'). Examples of these 'pier dwellings' can be seen now in Lau Lagoon, Malaita, Solomon Islands, where stone platforms are constructed, and house piles are then sunk into these (Figure 4.6). A variant of this 
latter type is the bracing of piles with boulders, as is seen in Figure 4.8, taken in Langalanga Lagoon, Malaita, Solomon Islands. Stone platforms that are sometimes as extensive as complete artificial islands are a distinctive feature of the large lagoons of Malaita in the Solomon Islands (Ivens 1930), and as structures fall into disuse and new ones are built, these blocks and boulders are often recycled. It is possible that it is this scenario we are witnessing in the western part of Kamgot, where boulders could have been brought in as the houses in the vicinity of TPs 21 and 23 were built in order to brace the stilt houses, and these boulders were removed to be reutilised elsewhere later in the occupational sequence. A large limestone stone boulder c. $45 \mathrm{~cm}$ in height was found in the basal deposits of TP 21. This stone would have had to have been brought in from outside the Kamgot area. Thus, the hard substrates required for the presence of the small, in situ natural gastropods would have been present for the duration of occupation and then moved when the structures were abandoned.

Also, in accordance with Gosden and Webb (1994:40) is the observation that sediments accumulate rapidly around stilt house structures, with the greatest volumes of Layer 2 sediments being in the western portion of the site at the edge of a sand spit. Indeed, as observed by Gosden and Webb (1994), the sand spit evident at Kamgot could have largely built up as a consequence of the presence of the site itself. The transient presence of imported boulders to shore up house piles could also help explain the 'baffling effect' (Gosden and Webb 1994:40) of stilts and their ability to capture and trap sediments.

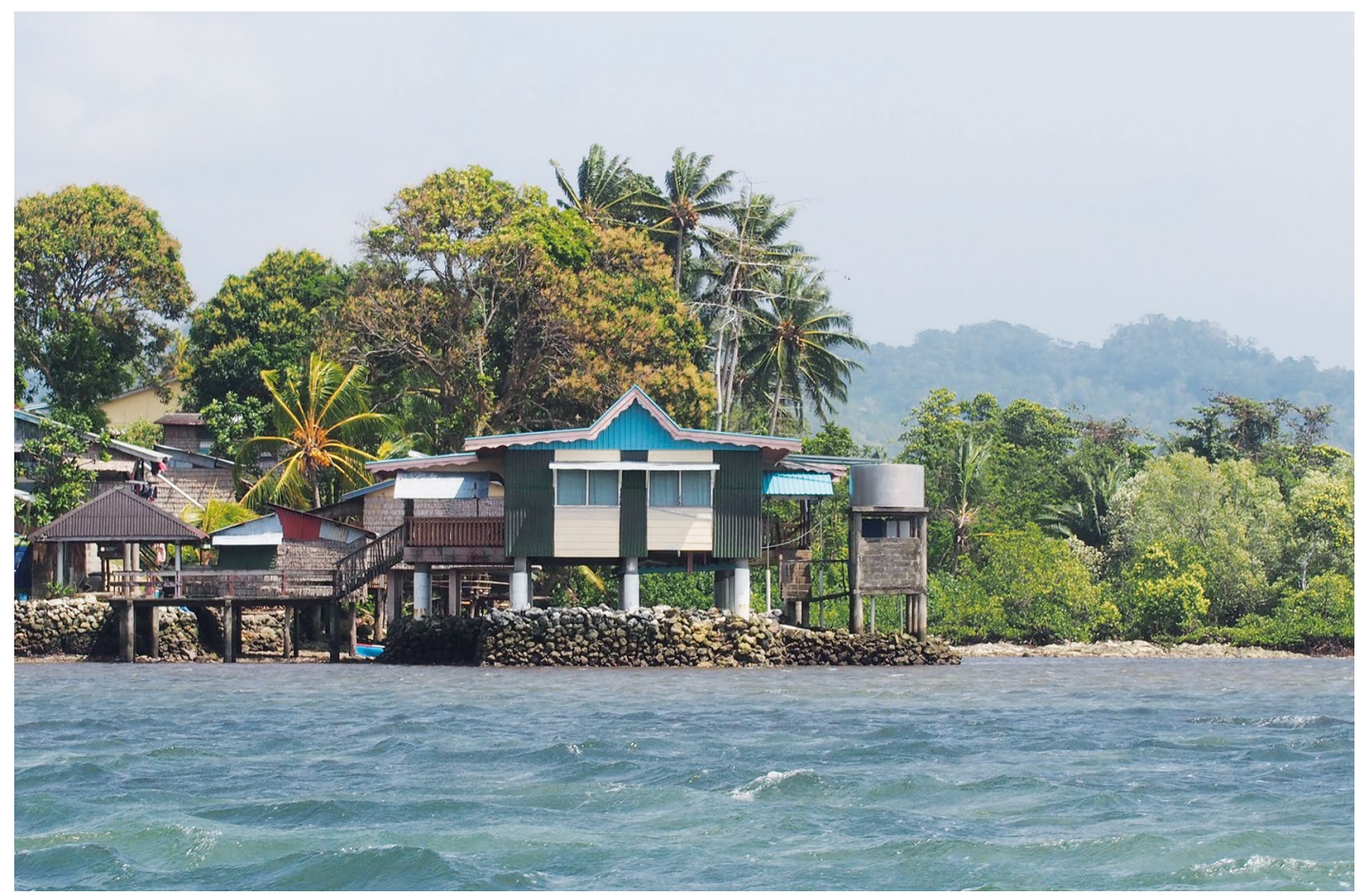

Figure 4.6. 'Pier dwelling' built into a purpose-built stone platform at Fouia Village, Lau Lagoon, Malaita, Solomon Islands.

Source: Katherine Szabó 2015. 


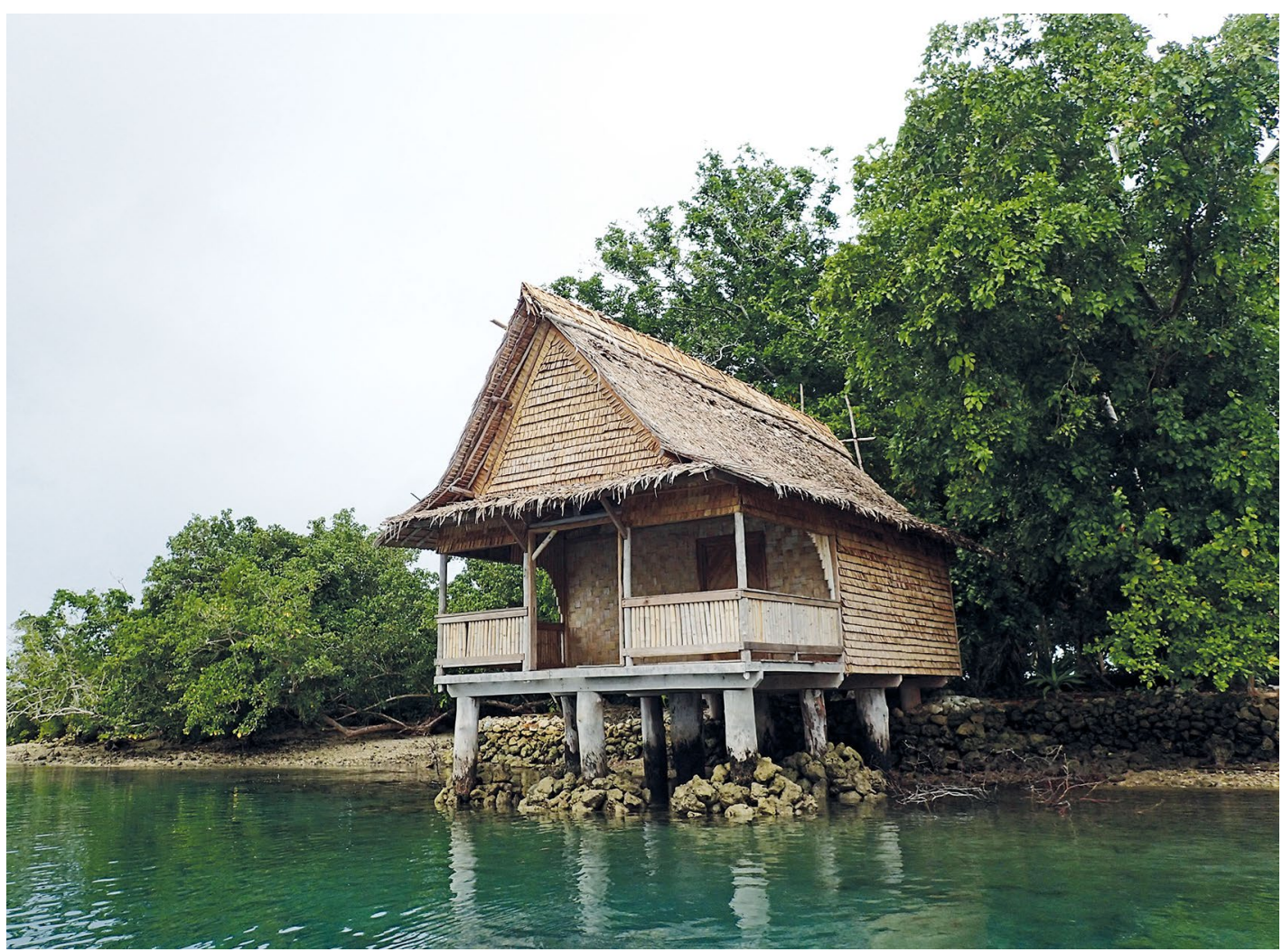

Figure 4.7. Dwelling in Langalanga Lagoon, Malaita, Solomon Islands, with limestone and coral boulders bracing sunken piles.

Source: Annette Oertle 2016.

\section{Kamgot chronology}

The chronology of the Early Lapita occupation of this site has already been published. Four radiocarbon dates are available for the earliest occupation and these are made up of two paired samples of charcoal and marine shell (Summerhayes 2001).

a. One paired sample from Layer 2 (spit 6) of TP 1 has dates of $3035 \pm 45$ BP (charcoal Wk7561 ) and $3260 \pm 45 \mathrm{BP}$ (shell Wk-7560) that calibrate to 3360-3080 cal. BP and 3350$2980 \mathrm{cal}$. BP at 95.4 per cent probability respectively.

b. The other paired sample from Layer 2 (spit 9) of TP 1 has dates of $3075 \pm 45 \mathrm{BP}$ (charcoal $\mathrm{Wk}-7563$ ) and $3350 \pm 45 \mathrm{BP}$ (shell Wk-7562). These calibrate to 3390-3160 cal. BP and 3450-3100 cal. BP at 95.4 per cent probability respectively.

For $\Delta \mathrm{R}$ corrections see Summerhayes 2007 and 2010. The conventional dates on shell are of a remarkably similar age to those from the assemblages from Mussau and the Arawes (Summerhayes 2007:146).

Subsequent occupation after the infilling of the lagoon is evident from TP 20, where Layer 3 was virtually culturally sterile, and initial occupation was in Layer 2 . This occupation at the base of Layer 2 dates from 3160-2990 cal. BP (on nutshell), while ages of 2920-2790 cal. BP (on burnt seed) and 2740-2500 cal. BP (from nutshell) are available from subsequent Layer 2 deposition. 


\section{From lagoon edge to surrounding habitats: Subsistence zonation and procurement}

The results presented above demonstrate that initial occupation at Kamgot was directly over water, with upper intertidal habitation following in concert with the building up of the sand spit and Layer 2 sediments. This position at the liminal zone of land and sea places the site at the interface of terrestrial and marine resources, and the relative split between the two is a question of interest. Elucidating the palaeoecology of the landscape and taphonomic processes of deposition is also critical in understanding what faunal remains are found (or not found) in the archaeological record of these Early Lapita societies. Chapter 18 (this volume) looks at how the physical placement of the site may have influenced access to, and consumption of, different subsistence resources.

Settlement at Kamgot confirms that stilt house occupation over beach and reef platforms is a feature of Early Lapita occupation. This is in contrast to later Lapita settlement, in particular in Remote Oceania where occupation was located on beaches or just inland. Stilt occupation over water in intertidal locations was absent in Remote Oceania, with the single possible exception the later Lapita site of Nukuleka in Tonga (Burley 2016). It was hypothesised here that with a higher sea stand of 1.2-1.4 m asl, plus a tidal range of 1.0-1.2 $\mathrm{m}$, then Lapita high tides were argued to have been 1.7-2.0 $\mathrm{m}$ asl beyond those of present-day levels for these Middle Lapita-aged sites, necessitating occupation on palaeo-islets with stilt houses for intertidal occupation (Burley 2016:87). Adding $2 \mathrm{~m}$ of water above present-day levels for $2850 \mathrm{cal}$. BP occupation on Tonga needs to be confirmed. It was not a feature of Middle and Late Lapita in Vanuatu, New Caledonia or Fiji. Stilt occupation over water was, however, found much later in Late Lapita to Post-Lapita occupation in New Georgia, in what could have been a late colonising phase back into the Solomons (see Findlater et al. 2009). Thus, its presence in Near Oceania and rarity in Remote Oceania could be due to a number of factors including a locational strategy against contracting malaria (Kirch 1997:112), or indeed a defensive adaptation against pre-existing populations.

\section{Acknowledgements}

We thank the National Museum and Art Gallery of Papua New Guinea, the National Research Institute of Papua New Guinea, the New Ireland Provincial Government and, most important of all, the people of Anir for permissions for this work to be undertaken. We also thank Nick Hogg for help with the Excel cross tabulations to produce the faunal graphs. This research was funded from an Australian Research Council Large Research Grant (A59530950) awarded to Summerhayes. Lastly, we would like to thank Stuart Bedford and Matthew Spriggs for their patience.

\section{References}

Abbot, R.T. 1991. Seashells of Southeast Asia. Graham Brash, Singapore.

Burley, D.V. 2016. Reconsideration of sea level and landscape for first Lapita settlement at Nukuleka, Kingdom of Tonga. Archaeology in Oceania 51:84-90. doi.org/10.1002/arco.5087.

Egloff, B.J. 1975. Archaeological investigations in the coastal Madang area and on Eloaue Island of the St Matthias Group. Records of the Papua New Guinea Public Museum and Art Gallery 5:15-31. 
Felgate, M. 2007. Leap-frogging or limping? Recent evidence from the Lapita littoral fringe, New Georgia, Solomon Islands. In S. Bedford, C. Sand and S.P. Connaughton (eds), Oceanic explorations: Lapita and Western Pacific settlement. pp. 123-140. Terra Australis 26. ANU E Press, Canberra. doi.org/10.22459/ TA26.2007.

Findlater, A.F., G.R. Summerhayes, W.R. Dickinson and I.A. Scales 2009. Assessing the anomalous role of ceramics in Late-Lapita interaction: A view from Kolombangara, western Solomon Islands. In P. Sheppard, T. Thomas and G.R. Summerhayes (eds), Lapita: Ancestors and descendants, pp. 101-117. New Zealand Archaeological Association Monograph 28. New Zealand Archaeological Association, Auckland.

Gosden, C. 1990. Archaeological work in the Arawe Islands, West New Britain Province, Papua New Guinea, December 1989-February 1990. Australian Archaeology 30:37-44. doi.org/10.1080/03122417. 1990.11681365 .

Gosden, C. and J. Webb 1994. The creation of a Papua New Guinean landscape: Archaeological and geomorphological evidence. Journal of Field Archaeology 21(1):29-51. doi.org/10.1179/0093469947 91549245 .

Green, R.C. 1979. Lapita. In J.D. Jennings (ed.), The prehistory of Polynesia, pp. 27-60. Harvard University Press, Cambridge, Mass. doi.org/10.4159/harvard.9780674181267.c3.

Ivens, W.G. 1930. The island builders of the Pacific: How and why the people of Mala construct their artificial islands, the antiquity and doubtful origin of the practice, with a description of the social organisation, magic and religion of their inhabitants. Seeley and Co., London.

Kirch, P.V. 1997. The Lapita peoples: Ancestors of the Oceanic world. Blackwell, Oxford.

Kirch, P.V. 2001. Three Lapita villages: Excavations at Talepakemalai (ECA), Etakosarai (ECB), and Etapakengaroasa (EHB), Eloaua and Emananus Islands. In P.V. Kirch (ed.), Lapita and its transformations in Near Oceania: Archaeological investigations in the Mussau Islands, Papua New Guinea, 1985-88, pp. 68-145. Contributions of the Archaeological Research Facility 59. University of California, Berkeley.

Lepofsky, D. 1992. Arboriculture in the Mussau Islands, Bismarck Archipelago. Economic Botany 46:192-211. doi.org/10.1007/BF02930638.

Matthews, P.J. and C. Gosden 1997. Plant remains from waterlogged sites in the Arawe Islands, West New Britain Province, Papua New Guinea: Implications for the history of plant use and domestication. Economic Botany 51(2):121-133. doi.org/10.1007/BF02893102.

Morton, J. and U. Raj n.d. The shore ecology of Suva and South Viti Levu. Introduction to zoning and reef structures. Soft Shores, Book I. University of the South Pacific, Suva.

Nunn, P.D. 2007. Echoes from a distance: Research into the Lapita occupation of the Rove Peninsula, southwest Viti Levu, Fiji. In S. Bedford, C. Sand and S.P. Connaughton (eds), Oceanic explorations: Lapita and Western Pacific settlement, pp. 163-176. Terra Australis 26. ANU E Press, Canberra. doi.org/10.22459/TA26.2007.

Sheppard, P. and R. Walter 2009. Inter-tidal Late Lapita sites and geotectonics in the Western Solomon Islands. In P. Sheppard, T. Thomas and G.R. Summerhayes (eds), Lapita: Ancestors and descendants, pp. 73-100. New Zealand Archaeological Association Monograph 28. New Zealand Archaeological Association, Auckland.

Summerhayes, G.R. 2000. Recent archaeological investigations in the Bismarck Archipelago, Anir, New Ireland Province, Papua New Guinea. Bulletin of the Indo-Pacific Prehistory Association 19:167-174. 
Summerhayes, G.R. 2001. Defining the chronology of Lapita in the Bismarck Archipelago. In G.R. Clark, A.J. Anderson and T. Sorovi-Vunidilo (eds), The archaeology of Lapita dispersal in Oceania: Papers from the Fourth Lapita Conference, June 2000, Canberra, Australia, pp. 25-38. Terra Australis 17. Pandanus Books, The Australian National University, Canberra.

Summerhayes, G.R. 2007. The rise and transformation of Lapita in the Bismarck Archipelago. In S. Chiu and C. Sand (eds), From Southeast Asia to the Pacific: Archaeological perspectives on the Austronesian expansion and the Lapita Cultural Complex, pp. 129-172. Centre for Archaeological Studies, Research Centre of Humanities and Social Sciences. Academia Sinica, Taipei.

Summerhayes, G.R. 2010. Lapita interaction: An update. In M. Gadu and H.-m. Lin (eds), 2009 International Symposium on Austronesian Studies, pp. 11-40. National Museum of Prehistory, Taitong, Taiwan.

Summerhayes, G.R., M. Leavesley and A. Fairbairn 2009. Impact of human colonisation on the landscape: A view from the Western Pacific. Pacific Science 63:725-745. doi.org/10.2984/049. 063.0412 .

Summerhayes, G.R., L. Matisoo-Smith, H. Mandui, J. Allen, J. Specht, N. Hogg and S. McPherson. 2010. Tamuarawai (EQS): An Early Lapita site on Emirau, New Ireland, PNG. The Journal of Pacific Archaeology 1:62-75.

Szabó, K. 2012. Terrestrial hermit crabs (Anomura: Coenobitidae) as taphonomic agents in circumtropical coastal sites. Journal of Archaeological Science 39:931-941. doi.org/10.1016/j.jas.2011. 10.028 . 
This text is taken from Debating Lapita: Distribution, Chronology, Society and Subsistence, edited by Stuart Bedford and Matthew Spriggs, published 2019 by ANU Press,

The Australian National University, Canberra, Australia.

doi.org/10.22459/TA52.2019.04 